\title{
DETERMINANTS OF GROWTH AND DEVELOPMENT OF COMPANIES FROM ELECTRO ENGINEERING INDUSTRY
}

\author{
${ }^{a}$ Jarosław Mioduszewski, ${ }^{b}$ Zygmunt Mietlewski \\ ${ }^{a}$ University of Warmia and Mazury in Olsztyn \\ ${ }^{\mathrm{b}}$ Gdynia Maritime University \\ a e-mail: miodus@uwm.edu.pl \\ b e-mail: mietlewski99@wp.pl
}

\begin{abstract}
Purpose: High employment costs caused by current legal-formal regulations in Poland are to be blamed by many entrepreneurs for the unsatisfactory dynamics of growth and development of their companies. They are also blamed for such short histories of the companies. Is that a right accusation? If yes then what impact would labour cost reduction have on growth and development of companies? This paper includes results of research on this issue.

Methodology: The opinion poll was conveyed with the use of questionnaires which were given to entrepreneurs, their employees and representatives of trade unions from enterprises which exist on the area of Warmia and Masuria Voivodship, who participated in seminars that are a part of program "The exchange of good practices in CSR in machinery industry in Poland and Bulgaria". The program was organized by Bulgarian Branch Chamber of Machine Building and Foundation "Institute of Corporate Social Responsibility in Olsztyn".

Findings: The results of the research show that labour cost reduction in enterprises would not lead to any significant changes in decision making nor it would result in activity that would enable growth and development of the company.

Originality/value: The importance of this paper is to verify the thesis claimed by many entrepreneurs, that labour costs imposed by the government are too high and they prevent growth and development of their enterprises. It has been shown that the thesis is not true, and that the entrepreneurs themselves are to be blamed for lack of growth and development of their enterprises, as it is caused by lack financial liquidity which results from belated payment of due amounts and obligations which also affects continuity of their businesses.
\end{abstract}

Key words: enterprise, decision making, labour cost, growth of a company, development of a company

Paper type: Research paper 
DETERMINANTS OF GROWTH AND DEVELOPMENT

Jarosław Mioduszewski, Zygmunt Mietlewski

\section{Introduction}

Politics, which has been shaped by two competing doctrines - liberalism and neoliberalism, influences behaviour and attitudes of entrepreneurs on the market. The political scene redefines values of the subjects on the market as well as, according to Czaputowicz (2007), it shapes "normative mood of the time characterized by four dimensions. The first dimension, determinism, is an opposition to the free will and it determines the influence on course of events. Realism dominates in the time of stable politics while when some changes are being introduced in politics, liberalism is the dominant doctrine. The second dimension, optimism vs. pessimism, refers to the direction of changes and it determines whether conditions are improving or not. Liberalism dominates in the optimistic times and realism in pessimistic times. The third dimension describes two opposite attitudes - competiveness and cooperation. Realism dominates in the times of competing for limited resources and constant comparing with others (the domination of philosophy of relative income), while in times of cooperation and comparing current situation to the past (i.e. philosophy of absolute income) dominates liberalism. The fourth dimension, elitism - egalitarianism, refers to the question whether world order should be decided upon by empires and their political-diplomatic establishment, as it is suggested by realism, or whether it should be decided upon also by smaller countries, and national and international public opinion, which is suggested by liberalism" (Czaputowicz, 2007). Economic relation is characterised by those two opposing economic theories that reflect different normative values. Changes in political or economic system cause domination of one theory over the other. For the time being the dominant theories are, interchangeably, realism and liberalism (Czaputowicz, 2007).

Liberalism is a doctrine that glorifies free market and private property. It stands against an interfering government and it postulates, or even demands, highly "limited budget redistribution and social politics". The boarder between liberalism and a rivalling neoliberalism is very thin. Neoliberalism, as Kołodko (2008) says in his book "Wandering world", “...does not serve true political democracy, economical efficiency nor social rationality, but rather exploits them for the sake of fulfilling needs of small elites, and not the needs of the population. Unfortunately one has to admit that it is being done effectively". Both competing theories agree that there is no growth nor development without capital. The author of "Wandering world" explains that growth and development can appear only if "there will be other things happening - phenomena and processes - that will result in higher production and higher standards of living due to an increased investment of capital. It all happens because development is a change for the better" (Kołodko, 2008). Growth and development require investment and “... one who does not invest, does not progress" (Kołodko, 2008). 
Economic activity of a company comes up to economic processes happening within the company such as production, service and trade. The direct result of those is profit. The durability of those processes depend on responsibility of the company towards its closest environment. The core of economic activity are the processes of exchange and accumulation of its product. The first process results from the division of labour while the second one, which is basically storing part of the production, is a result of planning production cycles and its storing for the future or for exchange for other products. Those processes have been going on for around 30 thousand years (Kozłowski, 2005) with various dynamics. Quite recently, barter transactions, where one good is exchanged for another one, were most common, then equivalent transactions, where goods are transferred for money, started dominating. The second type of transactions emerged from a long process of developing exchange and it influenced the birth of trade which was also influenced by accumulation.

The division of labour improved the efficiency of work, though in the past it was just a simple and static reproduction on a steady level, which varied depending on the motivation of the era [1]. Nowadays, in the times of globalisation, the division of labour is highly complex and motivation is extremely important. Employees are considered to be the biggest value of companies that are run in an innovative way. The traditional companies, which consider employees as a cost, are still dominant on the market. Nevertheless in both cases, while reducing costs, labour costs are the first to be reduced, despite being company's "biggest value". As Adam Smith (1954) says in his work The Wealth of Nations "one does not expects lunch from friendliness of a butcher, a brewer or a baker, but from their solicitude for their trade. It's their egoism that one addresses, not their humanity...". Following the Amartya Sen's translation of Adam Smith „As a butcher, brewer and baker need our money and we need their products, the exchange is satisfactory for both sides. It seems that it does not need to be labelled as business for both sides to see the improvement of their situation. One just has to mind their own business and market will take care of the rest and everyone will be satisfied" (Sen, 1995).

Since the ancient times people have fed their natural need of exploring the world through travelling and trading. Various circumstances forced them to face the unknown and in order to fulfil their egoistic needs, they had to exchange goods and acquire knowledge which developed their entrepreneurship. One can see the path that must have been followed by the Internet, which nowadays allows us to travel and trade around the world even without leaving our homes. Undoubtedly it would shock Phoenicians, who were the first to trigger "... the process of development of equivalent economy, which could not have been stopped later on" (Kołodko, 2008). The only thing that changed in the years were aims of the company owners, as the core economic activity of enterprises has not changed, and it is still production, accumulation and trade of goods. The thing that has changed 
DETERMINANTS OF GROWTH AND DEVELOPMENT

Jarosław Mioduszewski, Zygmunt Mietlewski is the aim of economic activity. It is power understood as money, any money. Enterprises which generate profit from various financial operations rather than from production (services), are also more valuable. In those enterprises cash flow and core economic activity depend on one another. Very often profit from financial operations provide funds for the main activity of the company. On one hand it generates real money, i.e. the money that has a reflection in production (services), and on the other hand it generates virtual money that does not have reflection in production (services). More often they gain profit through speculation rather than by competing with their production (services). In a long perspective it weakens their development and lowers their forethoughtfulness (entrepreneurship), as well as it causes stronger disappointment of the society (Mietlewski, 2015).

In the times of prosperity big companies tend to centralise, while in the times of non-prosperity they decentralize themselves. In the times of crisis they focus on short-term decisions, while in the times of prosperity they focus on long-term decisions. SMEs, in which an entrepreneur is both the owner and the manager of the company, the economic activity is rather spontaneous and its dynamics is based on element rather than on knowledge. In the phase of growth, entrepreneurs try to convince themselves and others that the growth of their company results from their experience and competence (Mietlewski, 2015).

The growth of a company is connected with the general growth of production level (value). This aim, as Kołodko (2008) explains, can be reached in two ways - by increasing employment or increasing the efficiency of current employees. It can also happen that the company increases the level of employment and the efficiency of new employees grows at the same paste without increasing the level of production per employee. Such growth does not cause the improvement of working conditions, nor the position of the company in the sector or on the market. The company and its employees can profit from the growth only if labour efficiency grows. Without that we cannot talk about development, we can even say that it is in opposition to the civilisation advancement which it just does not follow. We can also look at the development of companies from another perspective which is the capital engaged. The growth of a company requires that its value grows or the productivity of the capital already engaged has to grow. The company that invests well can grow, but the growth of the productivity of the capital has to result in higher labour efficiency. It has a direct influence on the paste of production growth and on improvement of labour conditions.

Kołodko (2008) notices that company's development is far more complex than growth. It happens through changes of both quantity and quality in: production, used techniques and production technology, investment, management and others. The dominant are rules of economic activity - strategy, as well as company's culture - its values. Moreover, the attitude of the company towards its natural environment also has a significant value. Triggering company's development 
requires that optimal strategies of growth are formulated and that they serve realisation of company's politics, which is neither easy nor simple. The estimation of level of growth and its dynamics is extremely difficult nowadays. Therefore one should ask a question "On what level is such model of growth and development of a company theoretically possible and practically achievable, so that it gives the company possibility to grow and develop sustainably compared to the sector, branch or even whole economy? (Kołodko, 2008).

Entrepreneurs working on an effective market [2] can be sure that their actions will result in discounting the available resources in a form of satisfactory synergy effect (lower costs, higher profit, gained knowledge, new skills) [3]. Therefore resources joining reflects in the level of profit (Koch, 1997), joining ,...two or more elements in order to achieve a result exceeding the sum of results caused by each element separately" (Supernat, 1998). All of that makes the economic activity more profitable (Mietlewski, 2003). Entrepreneurs believe that their partial competencies in the sphere of organisation and management, will be omitted by the market efficiency [4]. The decision on starting economic activity, or on its continuation, is being done even when it should not be. Intuitively they even "feel" that, if the simulation of calculation is against their odds and there is a very small opportunity of gaining reasonable, but fast profit, it will be levelled by the risk of possible loss. Such behaviour and attitude of entrepreneur are considered to be rational, but not optimal. According to Wawrzyniak (1997) "In majority of cases rationality is not optimal, therefore it is not the best (...) the analysis of problems of decisional rationality resembles divagation on luck".

Rationality is an immanent feature of entrepreneurs that is revealed in the process of decision making. According to Peters (1997), its lack would strip the economic activity from "life" by bringing it to the state of balance and "...balance of a system means death". Rationality can be understood in various ways, as "... ability that can be named as subjective rationality, as it is always someone's ability Although, in order to decide whether one's behaviour is rational or not, one has to know beforehand what rationality is, what it is characterized by and what it is made of. Then, we are talking not about ability, that can be possessed on various levels, but about certain rules independent from people's skills. In such case it rather dependents on their ability of logical thinking, which is a feature of some people who use the formal rules of logic" (Chmielecki, 1999). Very often it is hard to say which actions are rational and which are not. Everyone agrees on one matter - that actions of entrepreneurs are unpredictable and they are not determined by any objective factors.

Commonly, entrepreneurs try to rationalize but they present others with unreal reasons of their behaviour. They create projections and assign their own negative features to others. They see success as their own achievement, and they blame others for their own failures. It all happens in a world where luck and determinism 
DETERMINANTS OF GROWTH AND DEVELOPMENT

Jarosław Mioduszewski, Zygmunt Mietlewski coexist and at the end they form order. According to entrepreneurs, their actions are always sensible and realistic. Very often, they have no control over impact caused by appearing unique opportunities, and only those can influence them to take a risk. While making decisions they would rather base it on their intuition rather than on possessed economical knowledge on the influence of labour cost reduction on growth and development of a company. As the results of the research show, reduction of labour costs would not result in fundamental changes in decision making nor in actions that could enable growth and development of a company.

\section{Research Methodology}

The aim of the research was to identify growth and development factors of companies from the sector of electrical engineering industry on the area of Warmia and Masuria Voivodship. The entrepreneurs search for the possibility of growth and development of their companies in lowering labour costs. In the opinion poll that was held, employers, employees and trade unionists were asked a question "How would your company spend the surplus money "gained" by reducing labour cost?". The answers received should allow answering such formulated question and should allow achieving the aim of the research. It should also allow answering the following, specific questions:

1) Does the company give and accept extended payment periods while selling/buying products and services?

2) How is the punctuality of payments for sold/bought products and services shaped?

3) Does the company give discounts and accept them in transactions with their contractors?

4) What decisions would be potentially made and actions taken by the managers in situation of reduction of labour cost?

5) How would the punctuality of payment of company debts be shaped in situation of introducing systemic labour cost reduction by the government?

The research was conveyed among 98 respondents from companies which act on the areas of districts piski, działdowski, kętrzyński, ełcki, bartoszycki and nidzki in Warmia and Masuria Voivodship, which benefited from the project "The exchange of good practices in CSR in machinery industry in Poland and in Bulgaria. The guide of good practices" organised by Bulgarian Branch Chamber of Machine Building and Foundation "Institute of Corporate Social Responsibility in Olsztyn" in years 2014-2015. In analysis and evaluation of the results the collected data was grouped according to the respondents representing employers, employees and trade unions. The biggest group was employers $(51,0 \%)$, then employees $(33,7 \%)$, while the representatives of trade unions formed the minority $(15,3 \%)$. Among the 39 examined companies there were 18 production companies, 
which produced cables, groups of wires for cars, production of machinery parts and $\mathrm{AC}$ as well as 12 companies giving services in the area of heat power engineering, professional training and accountancy. The smallest group were the representatives of companies which sell electro engineering tools ( 9 companies).

The analysis and evaluation of collected results used algebraic analysis, and the deduced correlations were pictured on graphs.

\section{Discussion}

Drucker (1992) indicates that the main role of the management of each company is making decisions and taking actions that would enable achieving sufficient economic efficiency. Managers take responsibility for economic results, and those are their reason for existence and authority in the company (Shim and Siegel, 2001).

In market economy, the trading sphere has more influence on achieving economic goals than on production. The majority of the decisions made by managers focus on realisation of the main aim, which is existence and development based on gained profit, as well as on maintaining financial fluidity which is a factor indispensable for functioning. One of the most important tasks of the managers is to manage the working capital, which, on one hand, allows increasing profitability of the held activity, and on the other hand, reduces the risk of losing financial liquidity. It is essential to make decisions on allowing extended payment periods for products/services for the contractors. The results of the research show that managements try to follow a, so-called, "golden rule of management" and they minimise the demand for working capital by financing it with mercantile credit, while making similar decisions in transactions with their contractors. As most respondents indicated financing the working capital with credit is considered to be more effective for their companies, especially in the opinions of the managers and the representatives of trade unions. Employees have slightly different opinion on the issue and they believe that their companies accept extended payment periods towards their customers. The differentiation of the opinions can result from the availability of data regarding transaction made for the specific groups of respondents (Figure 1).

The favourable conditions of payment for received products/services should be reflected in punctual payment of due amounts by contractors and payment of obligations to their suppliers. Unfortunately, as most respondents indicated, the favourable conditions does not result in punctuality of payment of due amounts by contractors nor in payment of obligations to the suppliers of products/services (Figure 2).

Realisation of the main aim, that is existence and development of the company, implies the necessity of gaining profit, which is achieved through maximizing sales of their products/services. One of the actions to be taken that can increase 
DETERMINANTS

OF GROWTH AND

DEVELOPMENT

Jarosław Mioduszewski, Zygmunt Mietlewski

\section{Figure 1.}

Allowing and using extended period of payment according to the respondents

Source: own report on the basis of the survey

Figure 2.

Punctuality of paying due amounts by contractors and paying obligations to suppliers according to the respondents

Source: own report on the basis of the survey

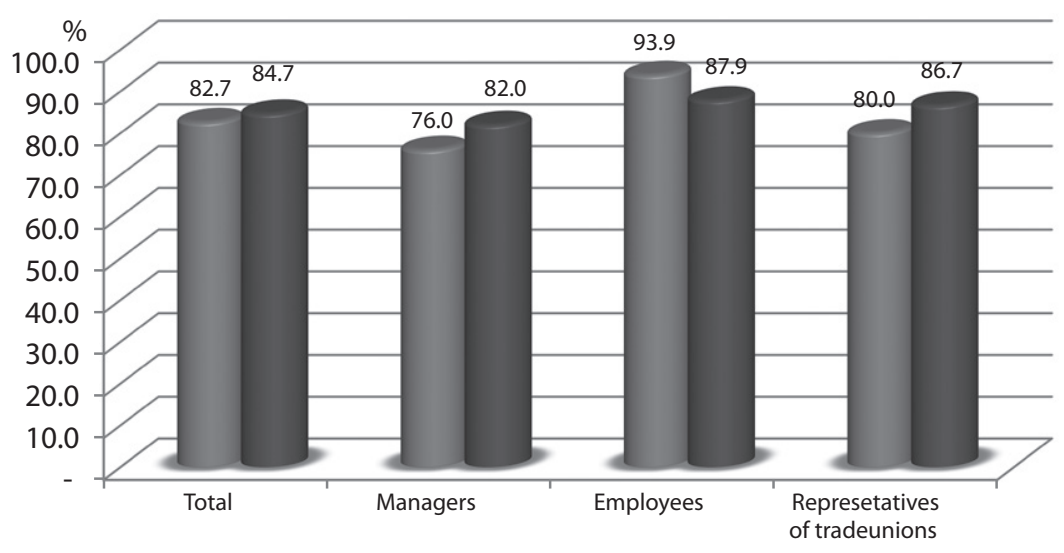

allowing extended period of payment forover 14 days

using extended period of payment forover 14 days

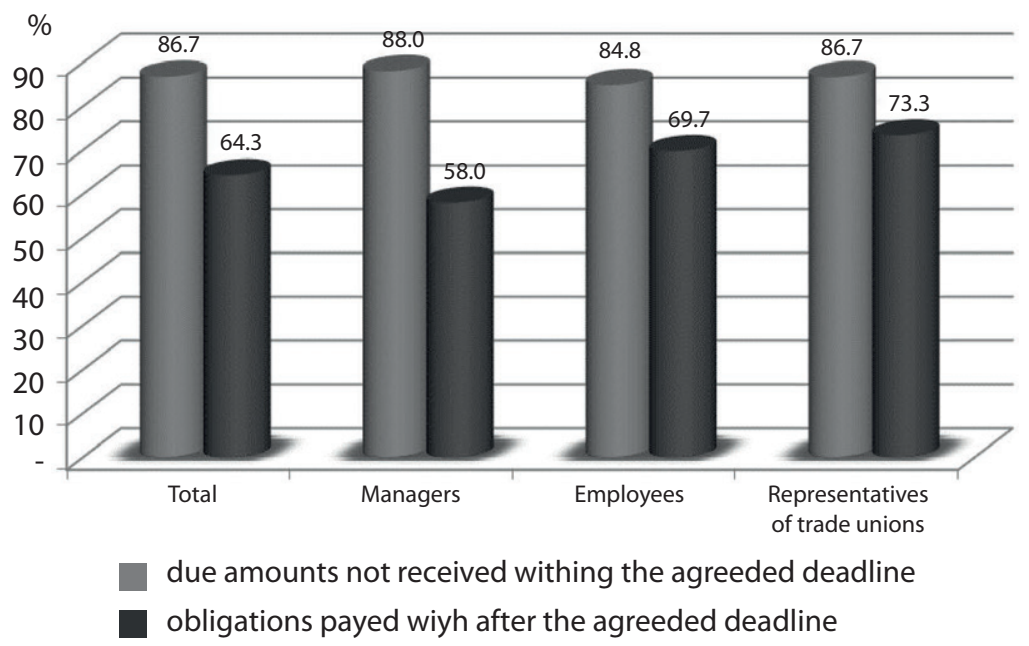

profit is sharing margin with contractors by using discounts for delivering and receiving products/services. As most respondents indicated, offering and using discounts by their companies has become some sort of a norm in running business and it is even considered to be an obligation of managers. In their opinions most interviewees indicated that their companies accept discounts more often than offer discounts to their contractors. The analysis of the results indicates that there should be link between accepted/offered discounts with the punctuality of 
payment in such a way that it would be more profitable to fund it with credit. Such solution could improve the punctuality of receiving due amounts, as well as the punctuality of payment of obligations to suppliers. The differences in assessment of sales/buying in different groups can result from more limited access to trade information for employees and the representatives of trade unions (Figure 3).

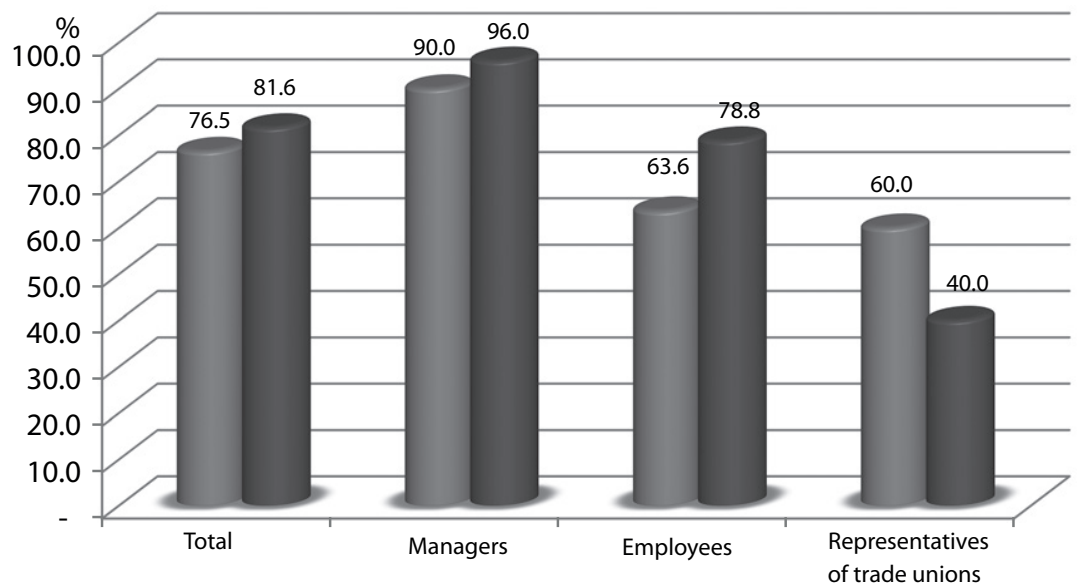

giving discounts to the customers
DETERMINANTS OF GROWTH AND DEVELOPMENT

Jarosław Mioduszewski, Zygmunt Mietlewski

Figure 3. Giving and using discounts by companies according to the respondents

Source: own report on the basis of the survey

As Einhorn and Hogart (2004) indicate, the decisions made always refer to the future and one has to decide, basing on the previous experiences, what will be done and in what way. They identify three phases of thinking back which are: looking for relevant variables, creating cause and effect chain, and finally evaluating its authenticity. In such process managers usually look for the explanation of various events in cases that were unusual. Finding proper variables that would explain what is happening they follow the track that allows them to find similar chains of cause and effect. They distinguished four categories of tracks that include:

- Order of events (where the causes proceed the effects),

- Closeness (coincidence of happening causes and effects at the same time),

- Correlation (convergence of the direction of changes in causes and effects),

- Similarity (the cause resembles the effect both in terms of durability and strength).

Even existence of the listed tracks is not always associated with existence of result. They are here to direct our way of thinking and they limit the possible scenarios of cause and effect chain.

The results of the research reflect this kind of cause and effect thinking in decision making with the simultaneous specific hypothetical event. It is essential to 
DETERMINANTS OF GROWTH AND DEVELOPMENT

Jarosław Mioduszewski, Zygmunt Mietlewski

Table 1. Potential decision making in the situation of lowering labour cost as a result of lowering the chargers on salaries according to the respondents

Source: own report on the basis of the survey evaluate possible decisions of the managers in situations of lowering labour cost by lowering the charges that are favoured over salaries by the government. According to the opinion of the respondents funds "gained" in such way would firstly fund investment associated with growth of the company $(55,1 \%)$. This answer was chosen mostly by the managers $(76,0 \%)$ and by the representatives of trade unions $(73,3 \%)$. Those two groups have most responsibility for the profit gained. Further decisions are associated with investment in growth of the company and resulted in the first place in increasing production/services $(39,8 \%)$, and then in increase of employment $(38,8 \%)$. The possibility of increasing the employment in times of lowering labour cost was assessed quite sceptically by the representatives of trade unions $(6,7 \%)$. Only $1 / 4$ or respondents assessed that lowering labour cost would result in lower prices for products/services for the customers. Such decisions are expected mostly by the representatives of trade unions $(66,7 \%)$ and they believe that it is a natural continuation of widely understood social justice. Every fifth respondent indicates that apart from lowering the costs, product/service prices will stay at the same level, and money earned will be invested in increasing production/ service capabilities (Table 1).

Proportion of votes: (in \%)

\section{Lp. Specification}

Total*

managers employees Representatives of trade unions

\begin{tabular}{llcccc}
\hline 1. & Investment in growth & 55,1 & 76,0 & 15,2 & 73,3 \\
\hline 2. & $\begin{array}{l}\text { Increase of production/ } \\
\text { services }\end{array}$ & 39,8 & 36,0 & 48,5 & 33,3 \\
\hline 3. & Increase of employment & 38,8 & 48,0 & 39,4 & 6,7 \\
\hline 4. & $\begin{array}{l}\text { Product/services price } \\
\text { reduction }\end{array}$ & 28,6 & 20,0 & 24,2 & 66,7 \\
\hline 5. & $\begin{array}{l}\text { Leaving products/services } \\
\text { prices on the same level }\end{array}$ & 21,4 & 26,0 & 9,1 & 33,3 \\
\hline
\end{tabular}

*several answers could be indicated

The punctuality of paying obligations by the company in the situation of labour cost reduction (lowering charges on salaries) by the government would be improved only in the opinion of $1 / 4$ of respondents. One might think that, apart from appearing, the cause would not result the way it is expected. Such evaluation indicates that companies would use the profit gained through lowering the charges on the salaries for improving their own financial situation in the first place, by investing in increasing their production/services capabilities. They hardly change their behaviour as they consider it to be a standard (Figure 4). 


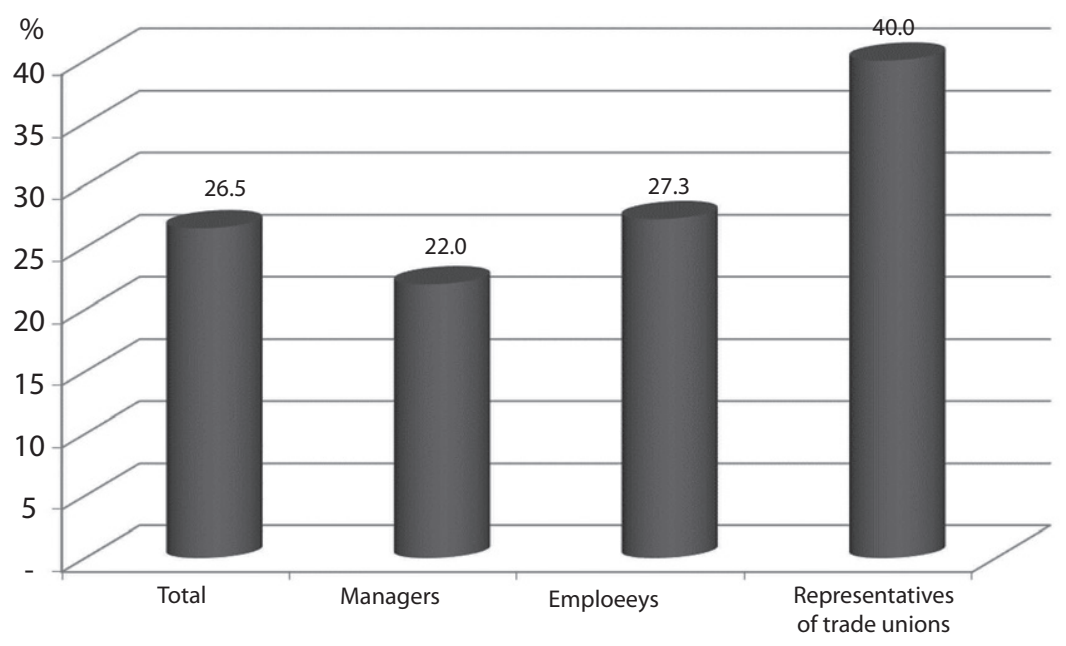

Figure 4.

Punctuality of paying obligations in the situation of lowering labour cost (charges on salaries) by the government according to the respondents

Source: own report on the basis of the survey

\section{Conclusion}

The results of the research allow us to formulate following conclusions:

1) Reduction of ,high labour cost" as a result of changes in law would not cause significant changes in decision making, nor in actions enabling growth and development of companies.

2) Using and giving discounts by companies has become a norm in running a business.

3) Favourable terms of payment do not reflect in punctuality of paying due amount by the contractors, not in payment of obligations to suppliers of products/services.

4) Apart from lowering labour cost as a result of legal changes in Poland prices of products/services will stay on the same level in $60 \%$ of examined companies. Also for $60 \%$ it would not be a reason to increase employment.

Explanation. The collected results indicate that decisions made and actions taken by companies are mainly determined by their economic situation and current norms of behaviour on the market. The evaluation of behaviour of participants on the market (sales/buying of products/services) indicate that financing operational activity with mercantile credit has become more common, together with simultaneous taking care of maintaining the balance between due amounts and obligations that result from extending periods of payment for products/services. Giving and using discounts is an inseparable element of trade and it has become a norm.

Considering hypothetical decisions made by managers in situation of lowering labour cost, the "earned" profit would be spent on increasing production potential through investment in production/service capabilities and level of employment. 
DETERMINANTS OF GROWTH AND DEVELOPMENT

Jarosław Mioduszewski, Zygmunt Mietlewski
Decisions referring to maintaining or lowering prices of products/services, in situation of lowering labour cost, would be made only by every fourth company. Similarly the respondents (around 1/4) assessed the possibility of improving punctuality of paying obligations. The results of the opinion poll indicate that companies use the profit gained through lowering labour cost to, first of all, improving their own operational activity, and some of it would be used to change norms of behaviour and rules functioning in trade.

Reassuming, it has to be indicated that the main objective of each company is maintaining its existence and development. Achieving this objective is strongly associated with growth of the company that can be reflected in increasing general level (value) of production through increasing employment and engaged capital or through increasing efficiency of company's employees or productiveness of engaged capital. Nevertheless, companies should introduce a number of changes in order to develop themselves that would refer to their direction, range, quality and scale of production/services, investment, used technologies and techniques of production/services. For development of companies it is essential that they follow current norms, rules and ethics of running a business.

\section{Notes}

[1] ,Money emerged from various places on Earth, not necessarily connected with one another. In some regions, there were countable and uncountable goods. In some places it was cattle - undoubtedly countable, but hardly divisible, sometimes it was specific metals; initially bronze, then silver and gold, and various alloys. Very often these were shells - even in places so distanced from one another like the Isles of Micronesia or Archipelago of Dos Bijagós by the costs of todays' Guinea Bissau. There, on Ilha de Rubane or Ilha de Joao Vieira, until today life goes similarly to the life of thousands years ago and the habitants, apart from barter transactions, keep using shells in exchange for freshly-caught fish. If necessary, they use regional CFA in trade with the external world, as well as dollars and euros", in: Kołodko, G.W. (2008), Wandering world, Prószyński i S-ka Publishing, Warsaw, pp. 65-66.

[2] On a market where ,... all publicly available information - both fundamental data and the track of prices - are already discounted for the current date. The changes happen only when the market receives new information. (...) The hypothesis of market efficiency basically says that market cannot be wrong as it is made of too many participants", in: Peters, E.E. (1997), Theory of chaos and capital markets, WIG-Press, Warsaw, p. 4.

[3] "Synergy results mainly from the fact that majority of cost can be shared. The bigger the shared costs are, the stronger the synergy." Mietlewski, Z. (2003), Methodology of data analysis and evaluation in budgeting economic activities of the unemployed, Institute of Organisation and Management „ORGMASZ”, Warsaw, pp. 53-54, [as in:] Stoner, A.J., Freeman, E.R., Gilbert, R.J. (1997), Management, PWE, Warsaw.

[4] The belief refers to the possiblity, while faith to the essence; here paradigm - Mietlewski, Z.

\section{References}

Chmielecki, A. (1999), Rzeczy i wartości. Humanistyczne podstawy edukacji ekonomicznej, PWN, Warszawa. 
Czaputowicz, J. (2007), Teorie stosunków międzynarodowych. Krytyka i systematyzacja, PWN, Warszawa.

Drucker, P. (1994), Praktyka zarządzania, Akademia Ekonomiczna w Krakowie, Kraków.

Einhorn, H.J., Hogarth, R.M. (2004), "Podejmowanie decyzji - myślenie wstecz i w przód”, in: Zarządzanie w warunkach niepewności, Harvard Business Review, Helion, Gliwice.

Koch, R. (1997), Słownik zarządzania i finansów. Narzędzia, terminy, techniki od A do Z, Wydawnictwo PSB, Kraków.

Kołodko, G.W. (2008), Wędrujacy świat, Prószyński i S-ka Publishing, Warszawa.

Kozłowski, J.K. (2005), Wielka historia świata. Tom I: Świat przed rewolucją neolityczna, Fogra, Kraków.

Mietlewski, Z. (2015), Quality of budgeting business in SMEs (writing paper), Wydawnictwo Akademii Morskiej w Gdyni, Gdynia.

Mietlewski, Z. (2003), Metodyka analizy i oceny danych w budżetach przedsięwzięć gospodarczych podejmowanych przez bezrobotnych, Instytut Organizacji i Zarządzania „ORGMASZ”, Warszawa.

Peters, E.E. (1997), Teoria chaosu a rynki kapitatowe, WIG-Press, Warszawa.

Sen, A. (1995), Czy pojęcie etyki biznesu ma sens ekonomiczny?, in: Minus, P.M., Etyka w biznesie, PWN, Warszawa.

Minus, P.M. (1995), Etyka w biznesie, PWN, Warszawa.

Shim, J.K., Siegel, J.G. (2001), Dyrektor finansowy, Oficyna Ekonomiczna, Kraków.

Smith, A. (1954), Bogactwo narodów. Tom I, PWN, Warszawa.

Stoner, A.J., Freeman, E.R., Gilbert, R.J. (1997), Kierowanie, PWE, Warszawa.

Supernat, J. (1988), Zarzqdzanie strategiczne. Pojęcia i koncepcje, Kolonia Limited, Wrocław.

Wawrzyniak, B. (1977), Decyzje kierownicze w teorii i praktyce zarzadzania, PWE, Warszawa. 